\title{
Bringing the Digital Library Design into the Realm of Enterprise Architecture
}

\author{
A. Abrizah and A.N. Zainab \\ Digital Library Research Group, \\ University of Malaya, Kuala Lumpur \\ Malaysia
}

\section{Introduction}

Previous digital library research and initiatives have conceptualized and proposed several frameworks for the design, development, evaluation and interaction of digital library systems. Levy and Marshall (1996) discussed a work-oriented perspective of digital library research that is based on the work people do, and how digital libraries assist in the completion of work related tasks. Their framework highlights three crucial characteristics of digital libraries: document, technology and work (which involves research and service). Moen and McClure (1997) identified a framework of five interacting dimensions in digital library of Government Information Locator Service (GILS): policy, users, technology, contents, and standards. The evaluation framework also includes three perspectives, representing the "views" of the stakeholders in the GILS: users, agencies, and the government. Marchionini and Fox (1999) identified four dimensions of digital library development: community, technology, service and content. Saracevic and Covi (2000) presented a framework, consisting seven levels, for examining digital libraries: social, institutional, individual, interface, engineering, processing and content. Another holistic framework is presented by Fuhr et al. (2001) consisting four major dimensions, namely data/collection, system/technology, users and usage. Sandusky (2002) developed a list of six attributes in framing digital library usability research: audience, institution, access, content, services, and design and development. Soergel (2002) offered a digital library research framework consisting of three guiding principles and eleven specific themes for research and development. Gonclaves et al. (2004) introduced 5S and formalisms for Streams, Structures, Spaces, Scenarios, and Societies - as a framework for providing theoretical and practical unification of digital libraries. All these frameworks emphasize the importance of a holistic approach rather than examine digital libraries as a single view, which would be limited in their utility.

However, the absence of common frameworks in the digital library development practices undermines the ability to develop and design digital library systems efficiently, to create large-scale collaborative activities, and to communicate the value of the systems to other communities. Gladney et al. (1994) wrote that the broad and deep requirements of digital libraries demand new frameworks and theories in order to understand better the complex interactions among their components. Supporting this claim, the summary report of the Joint NSF-European Union (EU) Working Groups on Future Directions of Digital 1 Libraries Research recommended that "new frameworks and theories be developed in order to 
understand the complex interactions between the various components in a globally distributed digital library" (Schauble and Smeaton, 1999). Formal frameworks are crucial to specify and understand clearly and unambiguously the characteristics, structure, and behavior of complex information systems such as digital libraries. The Digital Library Federation (DLF) in 2005 sponsored the formation of the Service Framework Group (SFG) to consider a more systematic, community-based approach to align the functions of digital libraries in fulfilling the needs of information environments (Lavoie, Henry and Dempsey, 2006). DLF envisaged that digital library functionalities be generated from the library business processes, considering the architectures as information systems with specific business requirements (Castelli and Fox, 2007). It is in this context, and in recognition of visions already underway to align digital library development with the emerging perspective of the Enterprise Architecture (Borninha, 2007), the authors conducted a study that seeks to understand and model the digital library services adopting a framework that give preference to scopes, goal requirements and processes - those concepts already common in Enterprise Architecture processes

Abdullah and Zainab (2008) regard a digital library as an enterprise that requires architecting. An Enterprise Architecture for the digital library is a framework or blueprint which shows how the digital library organisation carries out an intended task and how the digital library will or can improve the processes. It shows how a digital library represents a special workspace for the user community, not only for search and access but also for the process or workflow management, information creation, sharing and exchange, and distributed workgroup communication. In order to identify what is required of a digital library in a specific context, a sound methodology is needed to establish an understanding of the digital library entire structure. A multi-faceted information services such as digital libraries may be examined along different dimensions and from different perspectives or views of the stakeholders. There is a need to identify potential users, their involvement and roles in the digital library, their attitude towards the technology, their perception of its potential use and how it fits within the digital library goals in general. In order to do this, a digital library enterprise is required, which is derived and based on empirical data and stand up to conceptual reasoning. This chapter shows how an established Enterprise Architecture can be adopted as a formal framework to guide the research, design and development of digital libraries, providing a precise specification of requirements against which the implementation can be compared for correctness.

\section{Enterprise Architecture}

In general, Enterprise Architecture is a framework that describes how an organisation develops, manages and uses information technology to optimally support its business functions (Kahn and Wilensky, 1995). Sometimes, the term refers to the group of people responsible for modeling and then documenting the information architecture; other times the term denotes the process of doing this work. More commonly, Enterprise Architecture refers to the models, documents and reusable items (such as components, framework and objects) that reflect the actual architecture (McGovern et al., 2003). In the EACommunity (http://www.eacommunity.com/) Enterprise Architecture is a framework or blueprint for how the organisation achieves the current and future business objectives. It examines business processes, information technology, software and hardware, local and wide area networks, people, operations and projects with an organisation's overall strategy. Each of 
these strategies has a separate architectural discipline (such as business, information, application, technical and product) and Enterprise Architecture is the "glue" that integrates each of these disciplines into a cohesive framework (Bolton, 2004) as depicted in Figure 1.

From these definitions, it is understood that Enterprise Architecture consists of the various structures and processes of an organisation. Following this understanding, it is known that an Enterprise Architecture model is a representation of those structures and processes. A good Enterprise Architecture model will depict the organisation both as it is today and as it is envisioned in the future, and will map the various views representing the architecture to one another. These views include both business-oriented perspectives as well as technical perspectives. The blueprint or framework of the enterprise would reveal detailed statements and processes that characterized architectural drawings. The detail drawings would be in any form, such as rich pictures, structured charts, data flow diagrams, Unified Modelling Language (UML) activity diagrams, database tables and entity-relationship model.

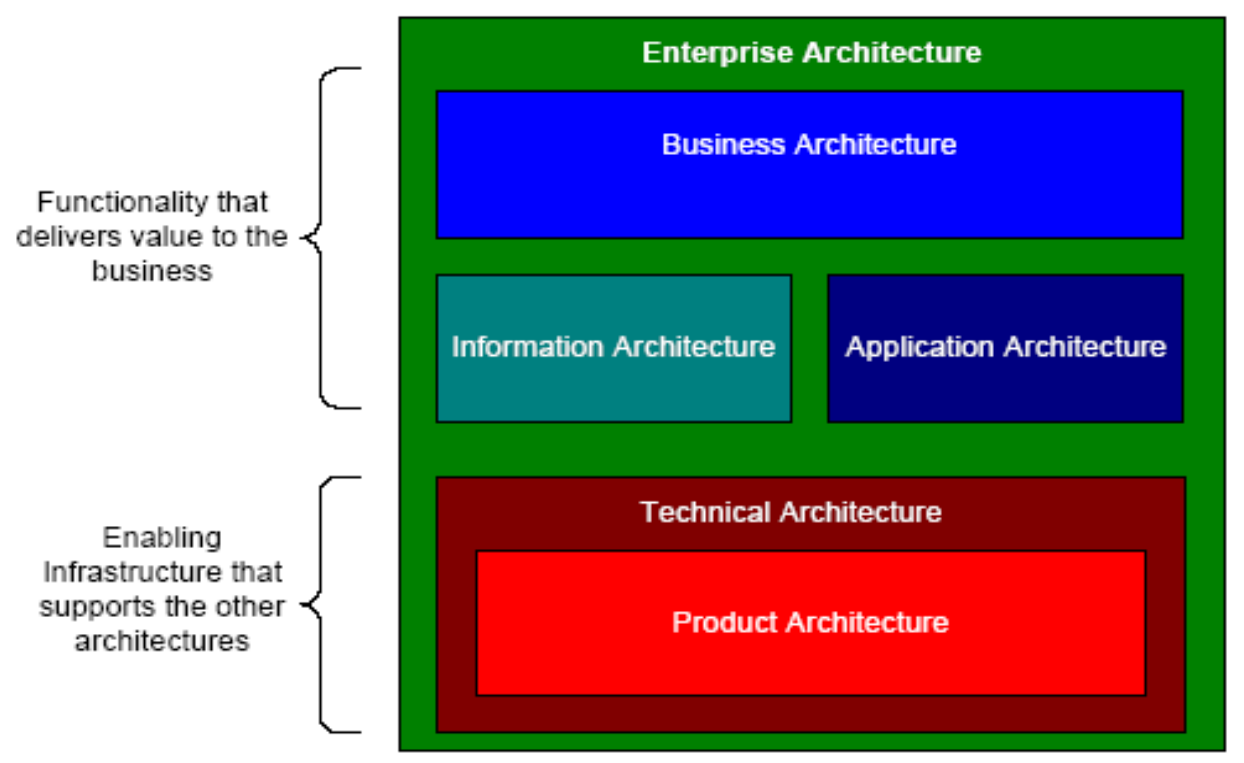

Fig. 1. Enterprise Architecture Relationship (Source: Bolton, 2004)

\section{Zachman Framework for Enterprise Architecture}

The Zachman Framework is a logical structure for classifying and organising the descriptive representations of the enterprise that are significant to the management of the enterprise, as well as to the development of the enterprise' systems (Zachman, 2002). The framework uses a grid model to provide a logical structure for classifying and organising the descriptive representation of an enterprise, in six different dimensions, and each dimension can be perceived in five different perspectives. In this framework, the architecture is described across two independent aspects, the rows represent the views of five different types of stakeholders (planner, owner, designer, builder and sub-contractor) and the columns represent six different aspects of the architecture (data, function, network, people, time and 
motivation). The points of intersection between the rows and the columns (between the views and the aspects) form cells. Each of these cells holds important information of the enterprise (also known as artifacts) that needs to be understood and explicitly declared. The Zachman Framework's enterprise design model is presented in Figure 2.

The Zachman Framework for Enterprise Architecture is found suitable to investigate the initial requirements and define the digital library organisation, processes, technology and information flows, as well as ground the design of digital libraries for the following reasons:

a. The framework helps to explicitly show the many perspectives that need to be addressed by the digital library. It requires the planner, owner and designer of the digital library to involve the stakeholders to ensure that it meets their needs and will be used. It holistically controls the approach to investigate the user requirements and guides the data gathering techniques.

b. The framework requires the involvement of stakeholders, not just the enterprise architects and developers. and ideally this practice is what digital library designers and developers should follow. This aligns with the need to involve stakeholders in digital library design and development.

c. The framework is robust enough. It explicitly shows and requires the designer to consider all aspects (What, How, Where, Who, When, Why) of the digital library design.

d. The framework is generic in nature (Pereira and Sousa, 2004) and can be applied perfectly to digital library organization. As such it is a flexible framework and it does not impose a method or restrict any user to a set of pre-defined artifacts.

This chapter shows, through a case study, how the three tiers of Zachman Framework - the contextual (scope) or planner's perspectives (Figure 2 Row 1), the conceptual (business model) or the owner's perspectives (Figure 2 Row 2) and the logical (system model) or the designer's perspectives (Figure 2, Row 3 ) - are used to design a digital library. The first two rows or layers are referred to as the Business Architecture (Figure 1) for they describe the functions a business performs and the information it uses. The third row refers to the information and the application architecture (Figure 1). The planner is concerned with positioning the digital library in the context of its environment. This is when the planner enquires about the demographics of the stakeholders, ICT individual differences, their readiness to participate and collaborate, their awareness of the concept of digital libraries and their perception of the digital library initiative. The owner is interested in the digital library's deliverable and how it will be used. The designer is concerned with how the digital library is to perform its functions. This involves investigating the resources that are used, the user behaviour of seeking for resources, the experience of searching, the relevance perceived and the problems encountered. The possible sets of constructs or artifacts to represent the cell content for each cell in the top three rows or layers of the Zachman Framework are presented in Table 1.

Row 6 of the framework represents the physical manifestation of the end product itself. Zachman (2003) says that technically Row 6 is not an architecture because it is not a representation (it is the actual thing), however it is useful to incorporate it into the framework graphic as it completes the architectural picture. For an enterprise employment of the framework, Row 6 represents the Functioning Enterprise, which is the end result of the architectural process. In this research, the end result is to ensure that Row 6 represents what the owners have in mind for the digital library enterprise at Row 2 . Therefore it is important to incorporate users assessment to evaluate the viability of a useful and enduring digital library system for the user community. This would involve assessment of the 
usefulness and usability of the system in terms of resources (data), processes (function), location (network), user community (people), time and goals (motivation).

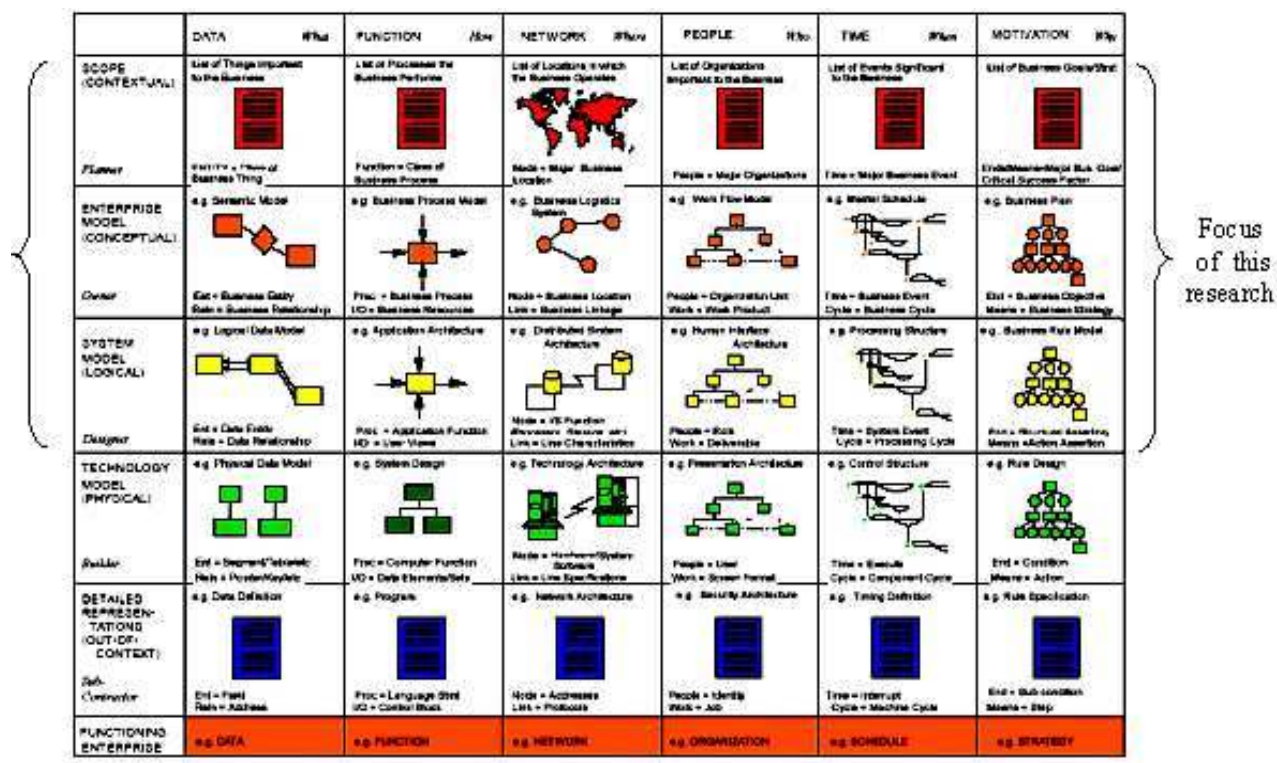

Fig. 2. The Zachman Framework for Enterprise Architecture (Source: http://www.zifa.com, 2006)

\begin{tabular}{|c|c|c|c|c|c|c|c|}
\hline & What & How & Where & Who & When & Why & \\
\hline $\begin{array}{c}\text { SCOPE } \\
\text { (Contextual) } \\
\text { Planner }\end{array}$ & \begin{tabular}{|c|} 
List of \\
things \\
important \\
to the \\
business \\
\end{tabular} & $\begin{array}{c}\text { List of } \\
\text { processes } \\
\text { the business } \\
\text { perform }\end{array}$ & $\begin{array}{c}\text { List of } \\
\text { location in } \\
\text { which the } \\
\text { business } \\
\text { operate } \\
\end{array}$ & $\begin{array}{c}\text { List of } \\
\text { people } \\
\text { involved in } \\
\text { the business }\end{array}$ & \begin{tabular}{|c|} 
List of \\
events \\
significant \\
to the \\
business \\
\end{tabular} & \begin{tabular}{|c|} 
List of \\
business \\
goals and \\
objectives
\end{tabular} & $\begin{array}{l}\text { SCOPE } \\
\text { (Contextual) } \\
\text { Planner }\end{array}$ \\
\hline $\begin{array}{l}\text { BUSINESS } \\
\text { (Conceptual) } \\
\text { Owner }\end{array}$ & $\begin{array}{c}\text { Semantic } \\
\text { Model }\end{array}$ & $\begin{array}{l}\text { Business } \\
\text { Process } \\
\text { Model }\end{array}$ & $\begin{array}{c}\text { Business } \\
\text { Logistic } \\
\text { Model }\end{array}$ & $\begin{array}{c}\text { Work flow } \\
\text { model }\end{array}$ & $\begin{array}{c}\text { Master } \\
\text { Schedule }\end{array}$ & $\begin{array}{c}\text { Business } \\
\text { Plan }\end{array}$ & $\begin{array}{c}\text { BUSINESS } \\
\text { (Conceptual) } \\
\text { Owner }\end{array}$ \\
\hline $\begin{array}{l}\text { SYSTEM } \\
\text { (Logical) } \\
\text { Designer }\end{array}$ & $\begin{array}{l}\text { Logical } \\
\text { Data } \\
\text { Model }\end{array}$ & $\begin{array}{l}\text { Application } \\
\text { Architecture }\end{array}$ & \begin{tabular}{|l||} 
Distributed \\
System \\
Architecture
\end{tabular} & $\begin{array}{c}\text { Human } \\
\text { Interface } \\
\text { Architecture }\end{array}$ & $\begin{array}{c}\text { Processing } \\
\text { Structure }\end{array}$ & $\begin{array}{c}\text { Business } \\
\text { Data Model }\end{array}$ & $\begin{array}{l}\text { SYSTEM } \\
\text { (Logical) } \\
\text { Designer }\end{array}$ \\
\hline \multicolumn{8}{|c|}{ TECHNOLOGY (Physical) Builder } \\
\hline \multicolumn{8}{|c|}{ DETAILED PRESENTATION (Out-of-context view) } \\
\hline $\begin{array}{l}\text { FUNCTIONING } \\
\text { ENTERPRISE - } \\
\text { The prototype }\end{array}$ & Data & Function & Network & People & Time & Motivation & $\begin{array}{l}\text { FUNCTIONING } \\
\text { ENTERPRISE - } \\
\text { The prototype }\end{array}$ \\
\hline
\end{tabular}

Table 1. Zachman Framework at the Contextual, Conceptual and Logical Systems Architecture 


\section{Formulation of an integrated framework for the collaborative digital library}

Collaborative digital libraries are constructed, collected and organized by a community of users and their functionalities support the information needs and uses of that community. Renda and Straccia (2004) viewed a digital library as a collaborative working and meeting space of people sharing common interests. Through a case study method, Zachman Framework is used as a basis to investigate the existing stakeholder's conditions and environment that would ensure the reception of a collaborative digital library for urban secondary schools use in Malaysia. In this digital library environment, students collaboratively build the digital library resources, which indirectly allow members of the community to be aware and be actively involved in local content development. The collaborative digital library would benefit both the students who would be the creator and publisher of digital project works and the teachers who would be given the experience of managing digital resources. The multi-method approach used in the case study, to ensure the consideration of all the aspects (dimensions) of a digital library system and the relationship of these dimensions in the framework used, has been reported elsewhere (Abdullah and Zainab, 2008). Findings were used to populate the Zachman Framework with contextual, conceptual, logical and module diagrams at every intersection between the columns (why, what, who, how, where, when) and the rows (scope, business model, system model). The framework abstracts the characteristics and features of the digital library based on the following six dimensions:

- Motivation factor, requiring the planner and owner to solicit answers to the "why" question, why there is need for the digital library? Why does the current business process need special handling such as those provided by the digital library?

- Data factor abstracts the "what" aspects of the digital library. What data that is currently handled by the stakeholders? What format would the data take in the digital library environment? What are the characteristics of the data used, processed, stored and presented or disseminated in terms of quality, accuracy, usability, description and organization?

- People factor looks at the "who" questions or the roles of people in the digital project environment. Who will be instructing? Who will be handling the data? Who will be reporting the collated or processed data? Are the players in the digital library environment "ready" to participate and contribute to the digital library initiative? Are they able to do so?

- Function or Process factor defines the "how" of the activities in the digital environment. How will users search for data, how will they store the data? How will students write, present and submit their project report? How will the teachers ensure that the students know what is required? How do they grade the reports? How will they keep the reports submitted for the specified time required by the Malaysian Ministry of Education? How can the school library or resource centre accommodate these reports?

- Place or Networks looks at the "where" factor. Where will the digital library be located? Where will it be accessed by the stakeholders?

- Time looks at the "when" aspects of the digital library. When will submission of reports take place? This is useful for designing schedules, the processing and control architecture and timing systems.

The next section illustrates the use of Zachman Framework in design of the digital library, focusing on all six dimensions of the framework from three perspectives. Each of these dimensions is investigated from the perspective of the planner (Row 1), owner (Row 2) and 
designer (Row 3) of the digital library. These perspectives help ensure that everything relevant to the digital library enterprise is covered. The columns, comprising the six dimensions, are arranged so that the most important column or the focus of attention is presented first. At the end, the outcome would be in the form of listings and diagrams depicting the scope, business and system model of the digital library. Rows 4, 5 and 6 are beyond the scope of this chapter.

\section{Case analysis of Zachman framework for the collaborative digital library}

\subsection{Motivation: why the digital library is needed}

Why (Motivation) column of Zachman Framework extracts the motivation of the people that support the realization of the digital library. This reveals the reasons for creating the digital library, as well as the establishment of goals, objectives and business plan of the digital library. The authors felt motivation aspect (stakeholders' motivation) of the framework should be first populated and given the most importance. The case study revealed that the educational community is ready to collaboratively build the digital library as reflected by the following findings (Abdullah and Zainab, 2006):

- Students are "Internet ready", as indicated by (a) high home computer ownership as such they are ready to utilize the digital library; (b) high Internet penetration either at home, school, cyber cafes or friend's houses; (c) a high number of students either have 3-4 years or more than 5 years experience in computer usage; (d) students regularly go online, between either every alternate days or everyday.

- Students are "digital ready" as indicated by their awareness, experience in using and preferring digital sources. The survey indicates that all students know how to word process; they know how to prepare slide presentations or draw using the computer, edit images, create multimedia and scan images, create web pages, database or undertake simple programming. This results show that they are aware and competent in handling digital resources, which is necessary when using digital library.

- Students are also moderately "Web ready" as they know how to use the web. Although most had no formal training, they learn how to use the Web by self-teaching, from books and people. The students also learn how to find sources on their own, from their parents and siblings or from their classmates and friends.

- Students are ready to collaboratively develop digital resources as they indicated sharing the resources they create or found with their friends either by e-mailing the URLs of websites, informing others through chat room or social networks or creating links to websites.

- Some students are "ready web publishers", as many of them either maintain a group web page, have their own personal web page or have been creating page pages for others. The results also show that the students have experience in creating digital resource over the Internet using webpage creator tools or HTML to develop their sites.

- Students do use the Internet for school related assignments or as a major source for their school project. Students sampled highly use the Internet resources to get information for the following subjects, History, Science and Geography. The results indicate that students believe that the Internet helps them with their school work.

- All students feel that there is a need for digital library of local information and feel that this would definitely benefit them. The results indicated very significant correlation between positive perception of the digital library with high Internet use, length of 
Internet experience, accessibility of Internet from home high self ratings of Internet skills.

- Teachers in the case study see the value of digital resources and online publishing for their students. They expressed the willingness to play the role as a facilitator in the digital library environment. They were keen on the digital library because students could contribute original works to be shared with other students, especially where some local contents are not available in textbooks. They believed students would be more careful in preparing their project report if they make it available to wider audience in the digital library environment.

- Teachers felt that a digital library would solve problem of storage and retrieval of reports submitted since project reports kept in resource room could only be retrieved by class name and level, and difficult to be retrieved by subject or topics of report or by specific student's name.

- The school's infrastructural facilities are ready to support a digital library as students can gain access to computers at self-accessed learning centres, especially for students and teachers who do not have computers or Internet access at their homes.

The above findings indicated that the readiness factors serve as motivating indicators, goals and objectives that support the plan for developing the digital library. Figure 3 presents the motivating factors that support the plan of the collaborative digital library.

The findings of the case study were plugged into the first three rows of the motivational aspect of Zachman Framework. In Row 1, the Planner's goals and objectives are defined in the form of vision statement that provides the strategic direction for the digital library. The digital library will support secondary students' information needs in conducting research projects through project-based learning (PBL). In PBL, students interpret, analyze, synthesize, generate, and evaluate information about a topic, collaborate with others, and produce a report (Blumfeld et al, 1991). To support students in these types of activities, a full complement of tools is needed to meet the unique needs of learners, and Internet technologies such as digital libraries have the affordances to support students in these activities. Based on this premise, as well as building from various illustrations of digital library initiatives' vision statement, the planner establishes the vision of the collaborative digital library to populate Row 1 of the Motivation column. The planner's vision of the digital library is as follows:

"The collaborative digital library should enable secondary students conducting history 1 school projects to access the information they need any time and any where, in a friendly, efficient and effective way, by overcoming the barriers o distance and language. The digital library should enable students to collaboratively contribute resources as the digital library is seen as a growing repository on Malaysian local history for education".

With the vision in mind, the planner establishes the following goals for developing and implementing the collaborative digital library:

a. the development of local historical resources;

b. provision of resources for lifelong learning;

c. provision of round-the clock access; and

d. development of community of users.

\footnotetext{
${ }^{1}$ History has been chosen as the domain of the digital library test-bed based on the survey findings that indicated the students surveyed mainly use Internet resources to get information for their History project. As such the domain of the digital library is collections of History project reports submitted by the secondary school students.
} 


\begin{tabular}{|c|c|c|}
\hline $\begin{array}{l}\text { School's technical } \\
\text { readiness } \\
\text { - ICT infrastructure } \\
\text { is in place } \\
\text { - New infrastructure } \\
\text { is planned } \\
\text { - Awareness of ICT } \\
\text { support system } \\
\text { - Implementation of } \\
\text { ICT mediated } \\
\text { learning }\end{array}$ & $\begin{array}{ll}\text { Students' ICT } \\
\text { readiness } \\
\text { - } & \text { High computer } \\
\text { ownership } \\
\text { - } & \text { Ease of Internet } \\
\text { access } \\
\text { - } \\
\text { Home access to } \\
\text { - Internet } \\
\text { - } \quad \text { Frequent users } \\
\text { Technologically } \\
\text { skilled }\end{array}$ & $\begin{array}{l}\text { Students' digital } \\
\text { readiness } \\
\text { - } \quad \text { Could use } \\
\text { digital resources } \\
\text { - } \quad \text { Strong } \\
\text { preference for } \\
\text { digital resources } \\
\text { - } \\
\text { Adequate } \\
\text { searching skills } \\
\text { - Familiar with } \\
\text { search agents }\end{array}$ \\
\hline \multirow{2}{*}{$\begin{array}{l}\text { Teachers' ready to } \\
\text { collaborate } \\
\text { - Value of } \\
\text { integrating with } \\
\text { subject learning } \\
\text { - See the value of } \\
\text { digital resources } \\
\text { - See the value of } \\
\text { online publishing }\end{array}$} & Motivating Factors & \multirow{2}{*}{$\begin{array}{l}\text { Acceptance of } \\
\text { digital library } \\
\text { - Perceive digital } \\
\text { library as useful } \\
\text { - Willingness to } \\
\text { contribute } \\
\text { contents }\end{array}$} \\
\hline & $\begin{array}{l}\text { Strategic readiness } \\
\text { - Master plan for } \\
\text { ICT integration } \\
\text { Budget borne by } \\
\text { government and } \\
\text { Parent-Teacher } \\
\text { Association }\end{array}$ & \\
\hline
\end{tabular}

Fig. 3. Motivating Factors that Support the Plan for Realization of the Digital Library

In this capacity, it establishes "a digital library service environment" - that is, a networked, online information space in which students can discover, locate, acquire access to and, increasingly, use information. The objective of the digital library is therefore to provide a learning environment and resources network for history education which is:

a. designed to meet the information needs of learners, in both individual and collaborative settings (enable the creation, organisation and maintaining of local history resources);

b. constructed to enable use of a broad array of materials for local history learning, primarily in digital format submitted by the educational community themselves (they themselves become resource providers); and

c. managed actively to promote reliable access anytime - anywhere to quality collections and services (provided over the Internet), available both within and outside the network.

Row 2 of the Motivation column identifies the owners' business plan that is the approach to use the collaborative digital library. The digital library is modelled to focus on serving students information needs in conducting research projects. As such, in the implementation of this digital library project, the use of the online resources would be an integral part of history projects-based learning activities. The digital library may move the student community towards an emerging digital resources and the submission of reports in the electronic form is therefore feasible. The implementation of the business plan (Figure 4) is consistent with the Ministry of Education's implementation and evaluation of History project, which will make the accomplishment of the goals and objectives feasible. The teachers on the other hand will be given the opportunity to validate the quality of submissions to maintain the quality of the digital library, grade the report online and add links to resources found on the Internet.

Row 3 spells out the the designer's perspectives which expressed the motivation of the digital library in the form of behavioural objectives. The objectives of the collaborative DL from the designer's perspectives are to: 


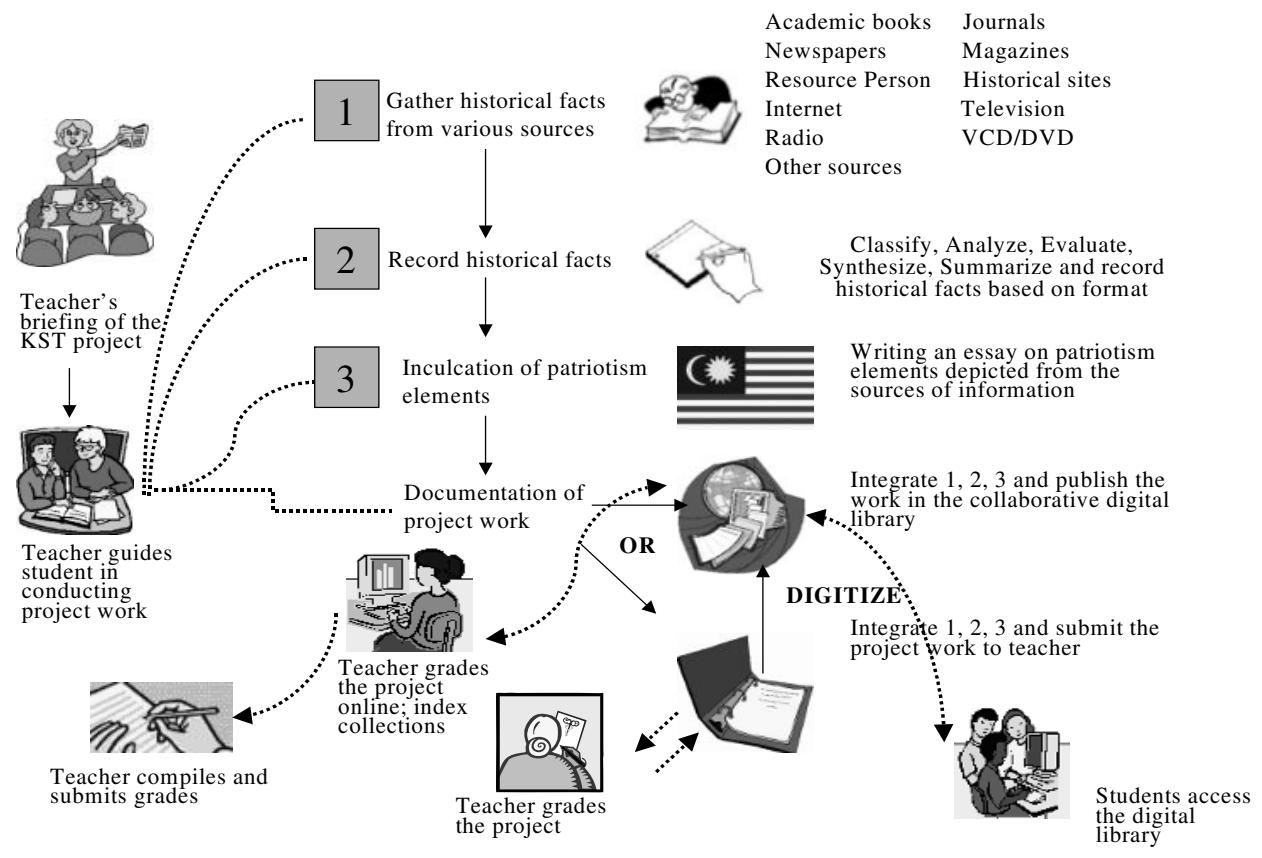

Fig. 4. The Business Plan to Use the Collaborative Digital Library

(Owner's View of Motivation)

a. Enable students to search and browse the digital library resources through various access points regarding the topics they are exploring

b. Allow the students to sequence and organize their project reports in various styles, construct references and append digital objects or pictures to their report.

c. Provide the students with the experience of publishing their project report, allow teachers grade and their friends to view the repot. The motivation for this is to satisfy their innate need to share their work, so that their peers can give comments for improvements before the report is finally submitted.

d. Allow teachers to check the suitability of submissions, maintain quality of contents of the digital library and grade the submissions.

e. Allow teachers and students to provide metadata for resources submitted to the digital library. A metadata schema (Dublin core) will be applied for this purpose.

f. Enable students and user groups to register as members to login and submit and describe resources

g. Allow users to submit feedback or submit useful links to other resources in the Internet.

h. Guide and assist users in using the digital library functions and services.

i. Allow authorized users to add, modify or delete submitted resources to the digital library.

These behavioural objectives of the digital library would assist the designer (Row 3) in developing the required digital library. The motivation and objective statements subsequently assist in the development of the user requirement and detailed definitions of the digital library services required in the Function (How) column of the Framework. 


\subsection{Data: what resources constitute the digital library}

What (Data) column of the Zachman Framework describes the digital library resources students used to fulfill their research needs. The data component, at the macro level identifies the information resources included or covered in the collaborative digital library, and at the micro level, concerned the collections, quality, accuracy, usability, description and organisation of the resources in the digital library. Findings from the case study revealed that the students and teachers emphasized the needs for contents to be "clear, accurate, adequate, organised, valid, reliable, informative and resourceful"

To cater for students' information needs, in Row 1, the planner describes the three main categories of resources (Figure 5), without policy-controlled access. The types of resources are (a) resources that are born digital; (b) digitised resources or digital proxies for physical items; and (c) Links to other resources relevant to the domain focus of the digital libbrary. The digital library collections incorporates not only digital resources in different media types such as text, images, web documents, audio and video, but also in different formats with different levels of content quality and metadata.

Row 2 of the Data column is a contiguous model of the resources expressed in terms of domain focus and topics seen by the owners of the digital library. History has been chosen as the domain of the digital library test-bed based on the survey findings that indicated the students surveyed mainly use Internet resources to get information for their History project.

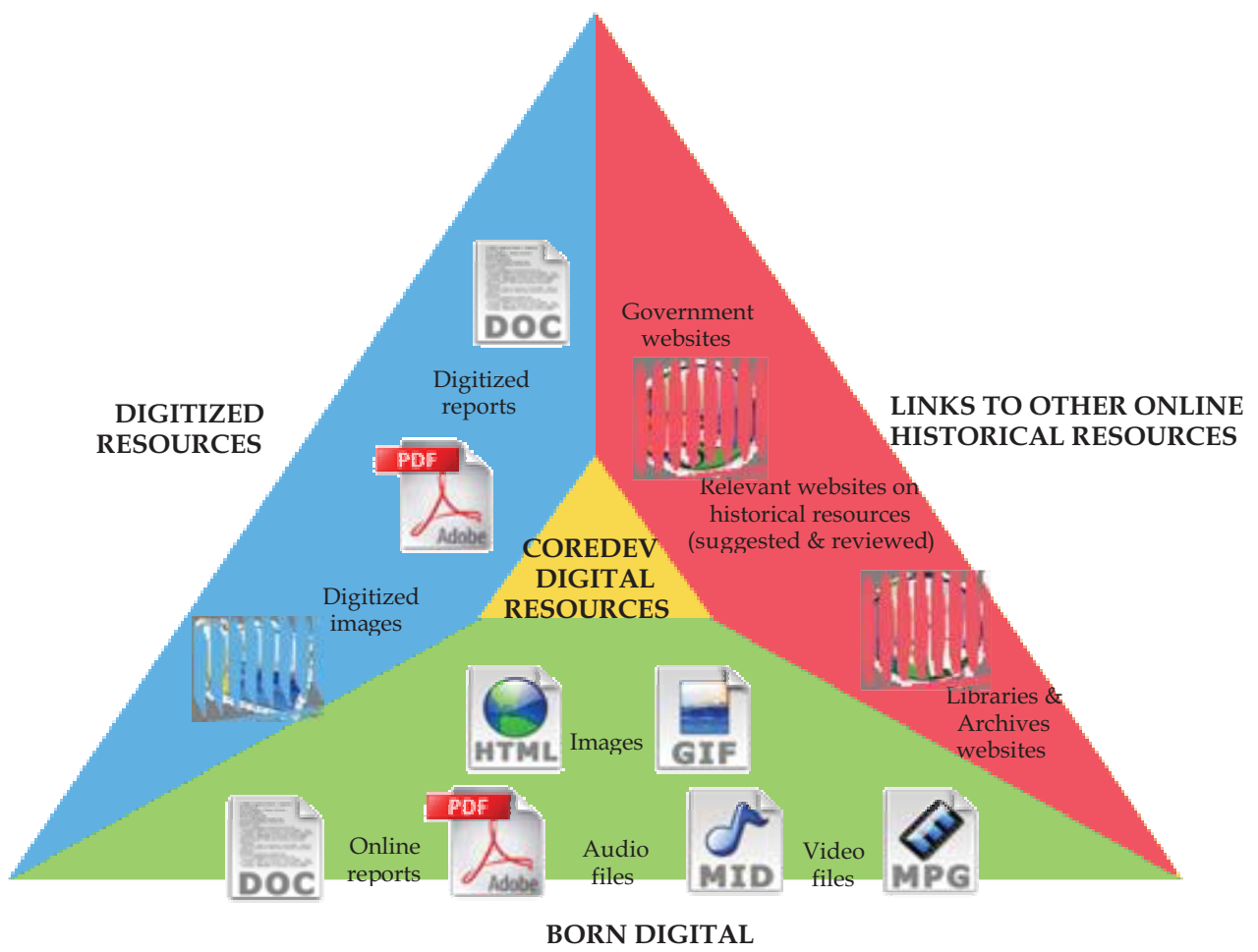

Fig. 5. The Digital Library Resources in Various Media Types and Format (Planner's View of Data) 
Case findings revealed that the project reports are typically made available in the form of collections, which refers to groups of resources organised around three themes or topic namely prominent personalities, historical events and historical buildings. Figure 6 presents the semantic description of the domain focus, contents, content criteria and scope of the collaborative digital library, which populates the Data component of the Zachman Framework. The stakeholders' needs for contents to be "clear, accurate, adequate, organised, valid, reliable, informative and resourceful" are therefore used as a set of general guidelines or selection criteria of resources accepted for submission.

From the designer's perspective (Row 3), the data of the digital library is expressed as table definition for the digital library data (comprising digital objects data and metadata, user information, annotation and static information pages) and metadata profile for the digital object resource description (comprising administrative, technical and descriptive metadata). Administrative metadata is created by the author, technical metadata is automaticallygenerated and descriptive metadata is assigned by the content access provider (human indexer). The descriptive metadata schema used for the object data description is the Dublin Core (DC) Metadata. The digital library has altogether 16 metadata elements and incorporates DC's 14 out of 15 elements, namely title, creator, subject, description, publisher, contributor, date, type, format, identifier, language, relation, coverage and rights. The DC source metadata element is not used. Two other elements incorporated are Collection and Ranking metadata.

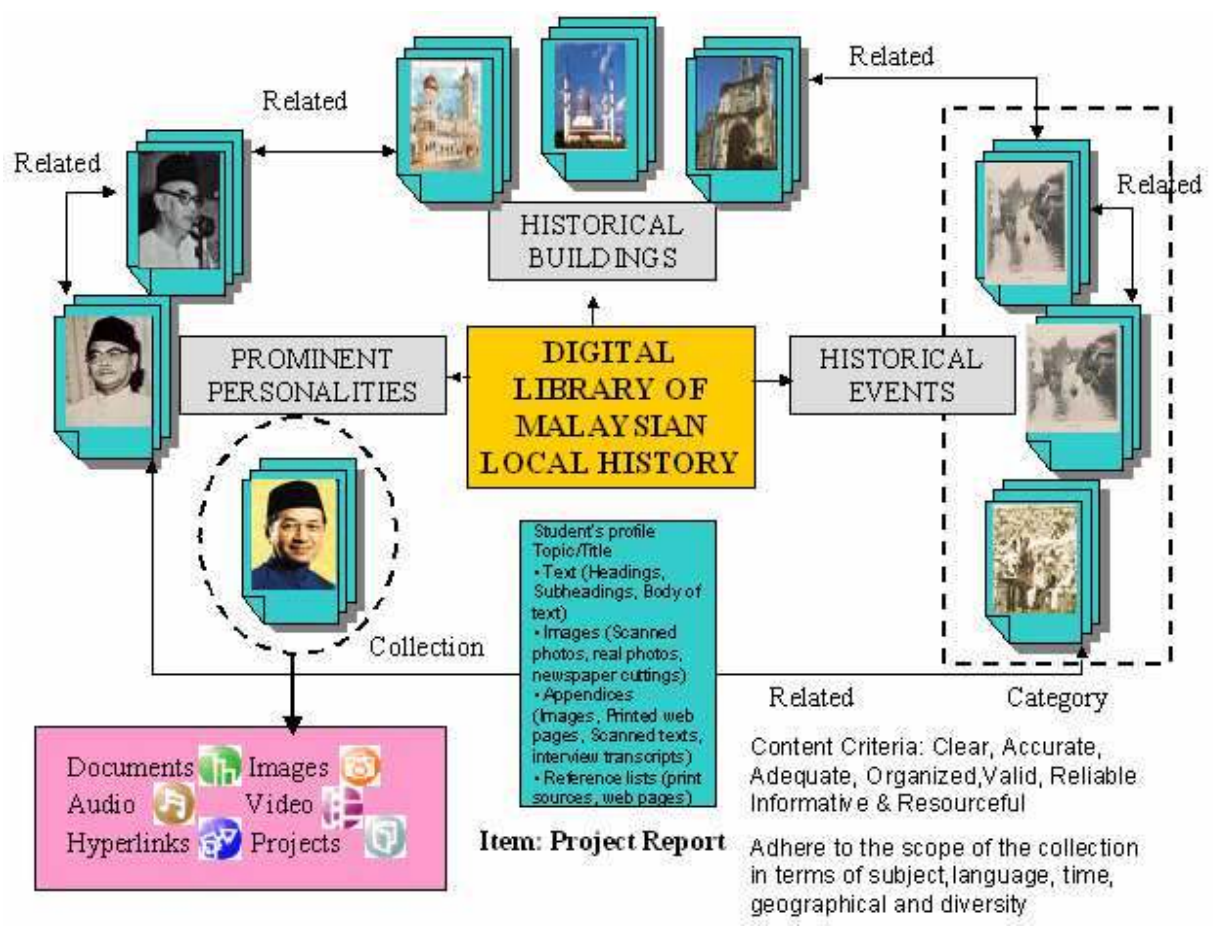

Fig. 6. Domain Focus, Contents, Content Criteria and Scope of the Collaborative Digital Library (Owner's View of Data) 


\subsection{People: who interacts with / within the digital library}

Who (People) column represents the stakeholders or the people within the digital library enterprise to which the digital library assigns responsibility for work. Thus, this component concerns the identification of the digital library users, their information needs, their usage of the Internet and online digital resources and their roles in the enterprise. The design of the enterprise has to do with the allocation of work and the structure of authority and responsibility. This column also deals with human-machine interfaces and relationships between the people and the work they perform.

In Row 1, the planner identifies the audience and the digital library organization. There are three types of audiences within the collaborative digital library enterprise, categorized as partners, guests and affiliate members (Figure 7). The planner identified these groups of people in the form of digital library organisational structure.

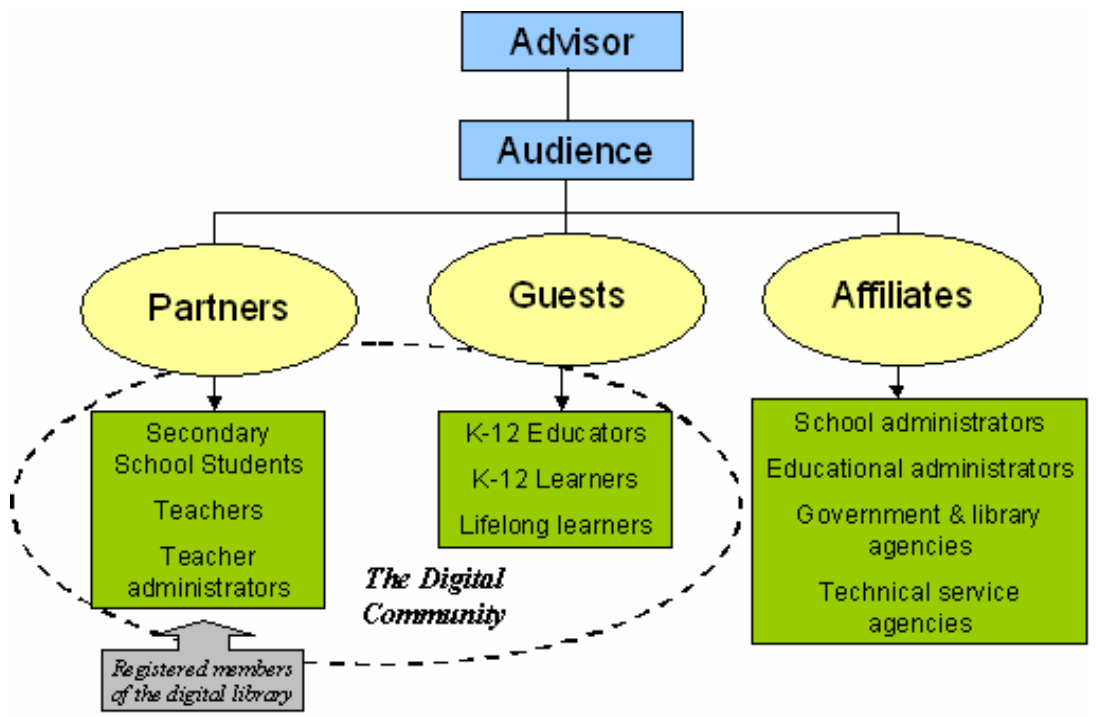

Fig. 7. The Digital Library Organisational Structure (Planner's View of People)

From the owner's perspective, Row 2 of the People Column illustrates the four main classes of people or actors and their respective roles in the collaborative DL. In this Consumer Content Provider - Content Manager - Administrator model, each class of actors represents a particular generic role. The digital community follows certain rules and their members play different roles, as consumers, content developers or providers, content access providers and content manager (Figure 8).

In Row 3, the designer fleshed out the interaction between actors and technology into a rich picture linked to the functional requirements (Figure 9). Here, the digital library community includes people as well as computers, agents, network connections, files and operating systems, user interfaces, communication links, and protocols, which either use or support the digital library services. The communities of autonomous agents and computers instantiate functions upon requests by the actors of the digital library. To operate, these agents and computers need structures of vocabulary and protocols. They act by sending streams of queries and retrieving streams of results. The digital library system uses the 


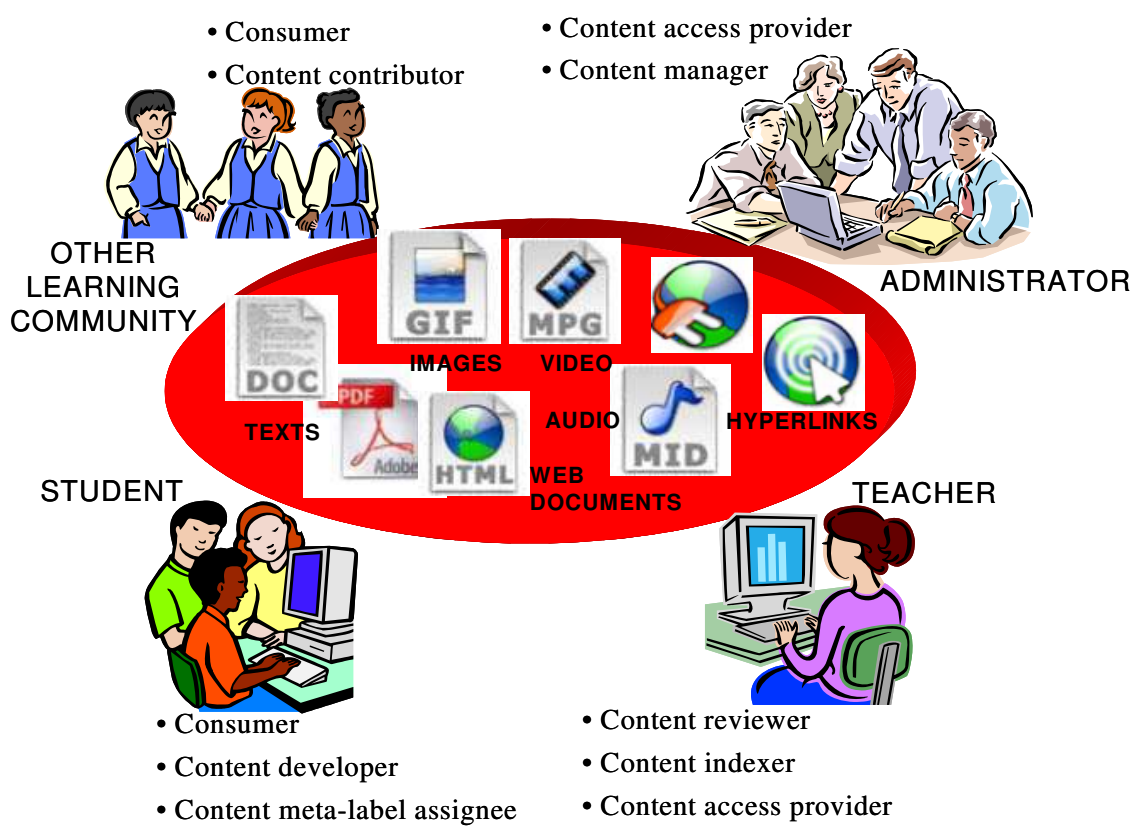

Fig. 8. The Digital Library Actor-Roles Diagram (Owner's View of People)

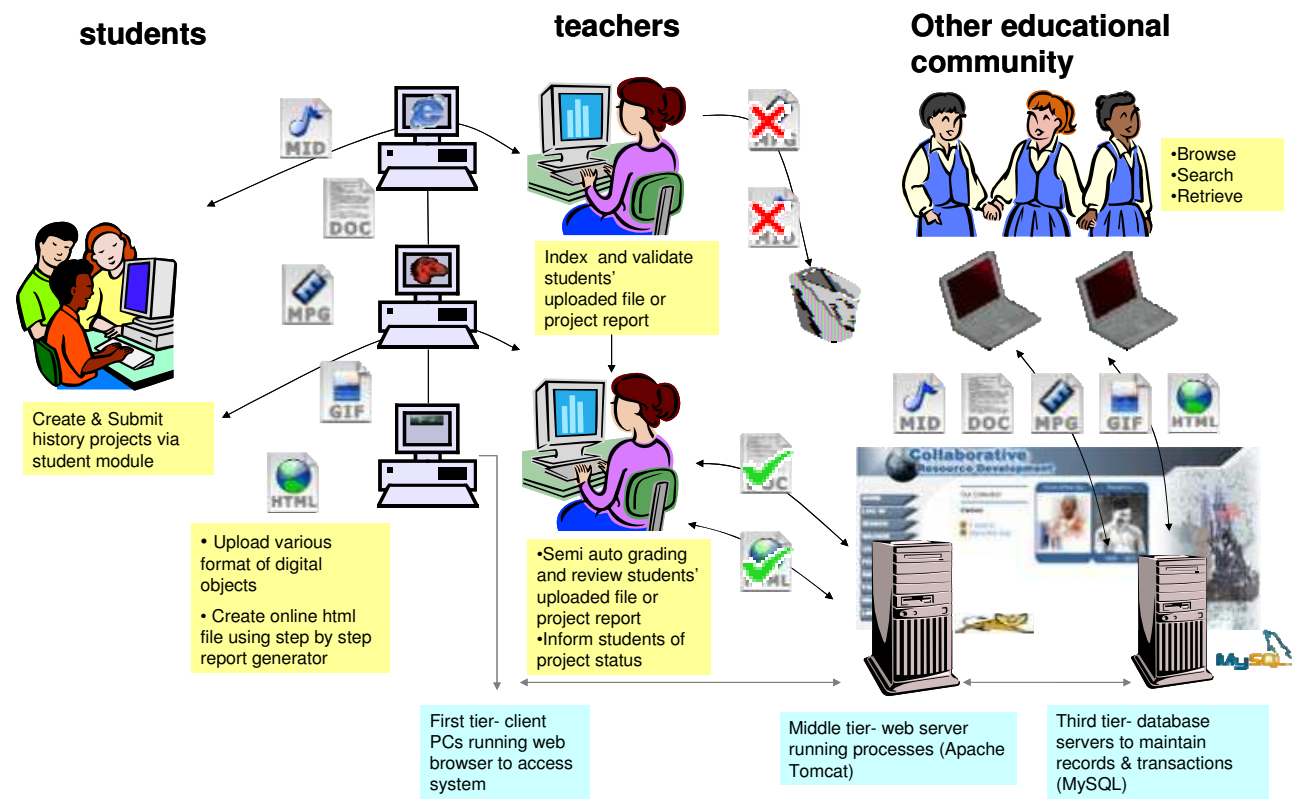

Fig. 9. Actors and Their Roles Depicted in the Digital Library Three-Tier Client-Server Architecture (Designer's View of People) 
three-tier client-server architecture. As depicted in Figure 9, the client tier comprises computers with web browsers such as Internet Explorer (4.0 or above), Netscape Navigator, Mozilla Firefox and Opera. User interfaces are provided for clients to process their application and manipulate their data. All application programmes reside in the middle-tier (web server). The web server processes the request from the client and then returns required result in web page format. It processes data request by linking to a database server (such as authenticating and validating users that login into the system). It is also linked to transaction server, especially when clients are uploading files to the web server. The third tier consists of the database server and transaction for maintaining data records.

\subsection{Function: what happens in the digital library?}

How (functions) defines the functions or activities the digital library enterprise is concerned about relative to each perspective. In Row 1, the planner describes the students' research activities that take place, which encompass the entire information seeking process (from recognizing the need for information to finding, using and presenting it) and the submission and evaluation of the information in the form of project report. This is presented in the form of rich pictures Basically, the students do solitary information seeking, have spontaneous interactions with other people such as parents, siblings and friends and ask for help, and work with information in a group. The description of the activities when conducting history projects are then transformed into the online activities the students and teachers would be able to perform in the collaborative digital library. Figure 10 presents the workflows and processes the collaborative digital library enterprise should conduct. These processes are also in line with the owner's plan to use the digital library for school project (Row 2 of Motivation). The function component refers to the activities students perform in their research, such as choosing topic, searching for information, organising resources, writing, presenting, submitting and teachers grading of project work.

Using data from analysis of the activities culled from the research (Row 1 of Function), formulation of behavioural objectives of the digital library (Row 2 of Motivation) as well as from the analysis of digital library functional requirements (Row 3 of Motivation), the planner develops the user requirement expressed in terms of functions and present it as services in a contiguous structured chart, The structured chart is comprehensible to the owner as the conceptual model of the digital library services (Figure 11). This structured chart populates Row 2 of the Function Column and describes the process of translating the objectives of the digital library enterprise into successively more detailed definitions of its services. Feedback from the stakeholders on the potential features of a service and digital library design implication derived from the analysis of the case study have helped to ascertain the main features required by the collaborative digital library.

In Row 3, the designer portrays the digital services in terms of data transforming processes, described exclusively in terms of definition of programme modules and how they interact with each other. The three system modules, namely administrators (including teachers), students and guests, provide different access types for different level of users. Along with this are specific definitions of security requirements, in terms of who (which role) is permitted access to what function, in the form of structured charts and detailed description of the modules menu. 


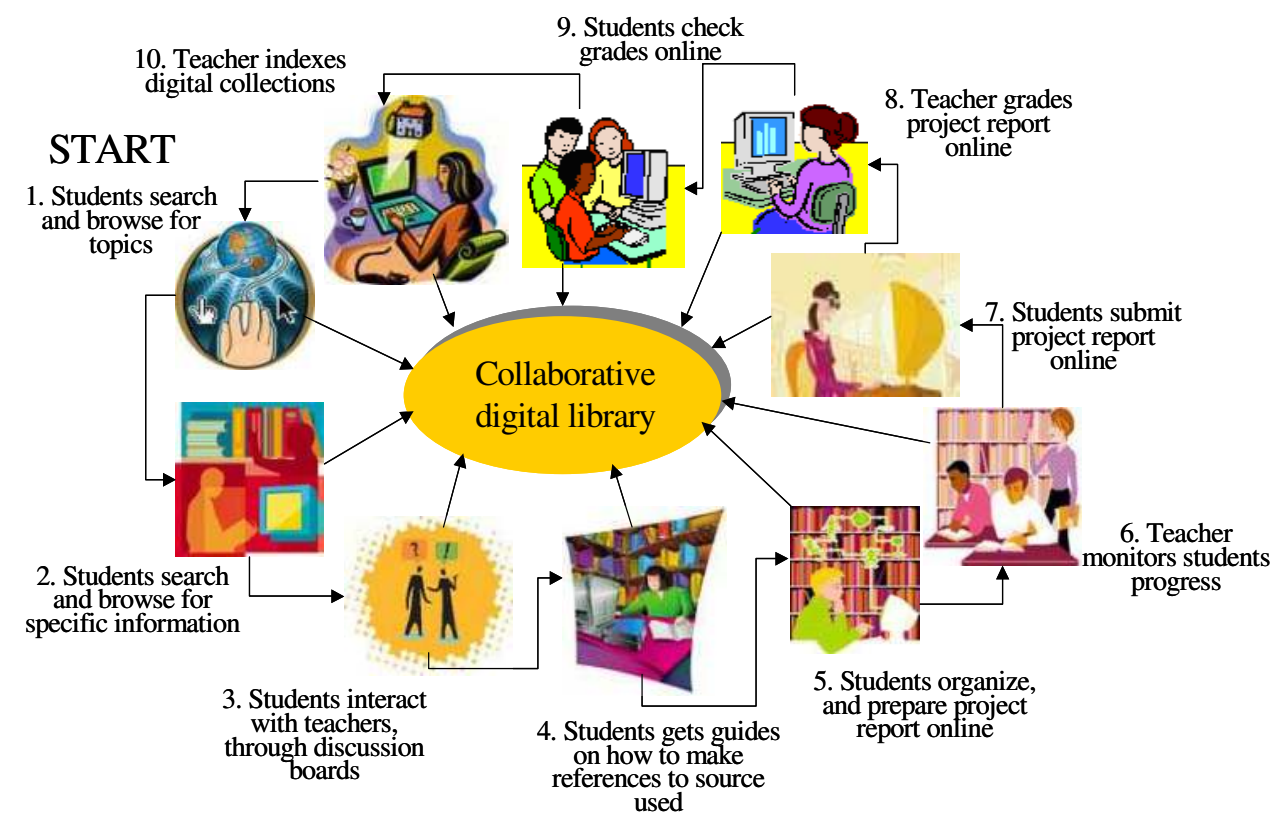

Fig. 10. Activities Performed in the Collaborative Digital Library (Planner's View of Function)

\begin{tabular}{|c|c|c|c|c|c|}
\hline \multicolumn{5}{|c|}{ COLLABORATIVE DIGITAL LIBRARY } & \\
\hline Authentication & Registration & \multicolumn{2}{|c|}{ Content creation } & \multicolumn{2}{|c|}{$\begin{array}{l}\text { Portal-enabled } \\
\text { Knowledge Tools }\end{array}$} \\
\hline $\begin{array}{l}\text { Login ID \& } \\
\text { Password } \\
\text { Verification } \\
\text { Login Status }\end{array}$ & $\begin{array}{l}\text { Display } \\
\text { registration form } \\
\text { Fills up form } \\
\text { Checks for } \\
\text { validity of form } \\
\text { Confirmation } \\
\text { message }\end{array}$ & \multicolumn{2}{|c|}{$\begin{array}{l}\text { Create and upload } \\
\text { report and digital } \\
\text { objects to database } \\
\text { Provides document } \\
\text { template and forms } \\
\text { to standardize } \\
\text { procedures }\end{array}$} & \multicolumn{2}{|c|}{$\begin{array}{l}\text { Provides value-added } \\
\text { functions: } \\
\text {-Quiz } \\
\text {-Personality of the } \\
\text { day } \\
\text {-Edutainment }\end{array}$} \\
\hline $\begin{array}{c}\text { Data } \\
\text { Manipulation }\end{array}$ & & Index & \multicolumn{2}{|c|}{$\begin{array}{l}\text { Search \& } \\
\text { Retrieval }\end{array}$} & $\begin{array}{c}\text { Tracking \& } \\
\text { Report }\end{array}$ \\
\hline $\begin{array}{l}\text { Provides } \\
\text { functions to } \\
\text { view, add, } \\
\text { modify or } \\
\text { delete records }\end{array}$ & $\begin{array}{l}\text { Provides general } \\
\text { information: } \\
\text {-FAQ } \\
\text {-Contact Us } \\
\text {-Terms \& } \\
\text { Conditions } \\
\text {-Help } \\
\text { - Related Links }\end{array}$ & $\begin{array}{l}\text { Indexing newly } \\
\text { added digital } \\
\text { objects using } \\
\text { Dublin Core- } \\
\text { based template }\end{array}$ & \multicolumn{2}{|c|}{$\begin{array}{l}\text { Searching by } \\
\text { keywords, } \\
\text { Browsing- } \\
\text { alphabetical, } \\
\text { thumbnail of } \\
\text { media objects } \\
\text { Display results } \\
\text { Retrieve \& } \\
\text { downloads }\end{array}$} & $\begin{array}{l}\text { Saves the } \\
\text { accessed } \\
\text { record } \\
\text { Generates } \\
\text { report } \\
\text { Displays report } \\
\text { to authorised } \\
\text { users }\end{array}$ \\
\hline
\end{tabular}

Fig. 11. Conceptual Model of Services in the Digital Library (Owner's View of Function) 


\subsection{Network: where can one access the digital library}

Network (Where) shows the sites or geographical locations and the interconnections between activities within the digital library enterprise. It illustrates the network-related aspect of the digital libraries in terms of the physical locations of members in the digital library which spread over a geographical area. The planner provides the big picture of the digital library as a centralized system with the control for the whole structure at the Faculty of Computer Science and Information Technology University of Malaya (FCSIT UM) as the developer of the digital library system (Figure 12). FCSIT UM group manages the centralized database server. School $\mathrm{A}$ is the content collaborator and joint owner of the system and other potential future collaborators such as School B, Education Departments, Ministry of Education, as well as other repositories, would be able to utilise the application server running locally to fetch the required data from the database server.

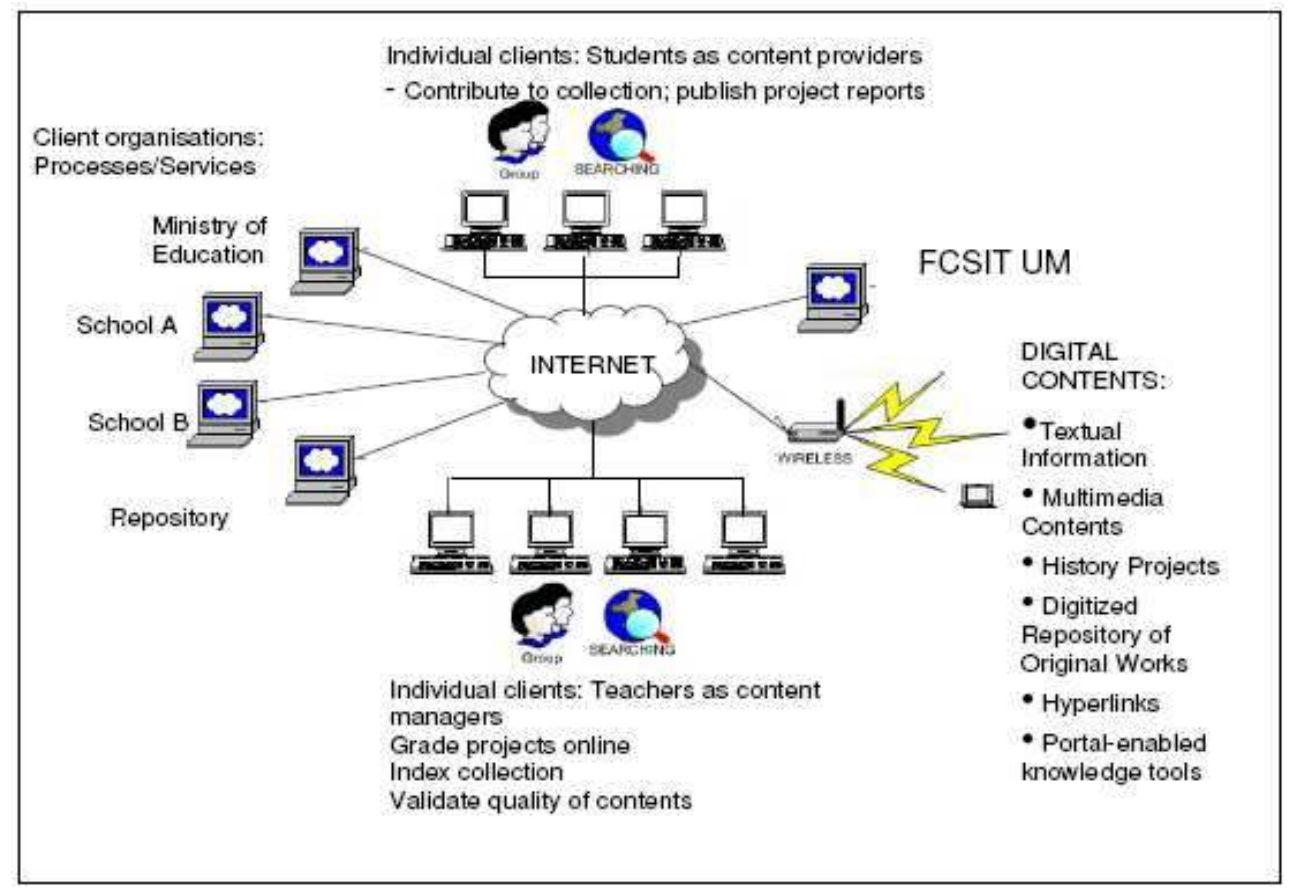

Fig. 12. The Physical Network of the Collaborative Digital Library (Planner's View of Network)

The owner is interested in the conceptual model of "Where" which includes the location of access and place where the primary stakeholders, namely the students and teachers use the digital library (Figure 13). It illustrates the collaborative digital library deployment expressed in term of location of access and computing facilities and network. The school community may access the collaborative digital library system from any 10 locations in the school, as all computers there are connected to the network.

From the designer's perspective, the Network Column presents the logical model of the network component of the collaborative digital library which depicts the types of systems 
facilities and controlling software at the nodes and lines such as processors/operating systems, database and lines/line operation systems. The notional distributed systems architecture (Figure 14) shows servers supporting the digital library services served from the regional (FCSIT) and local data center environment to the school's three primary locations of access. It is referred to as a notional architecture since the extent of the ability to remotely serve specific applications in both the baseline state and the target state remains to be established.

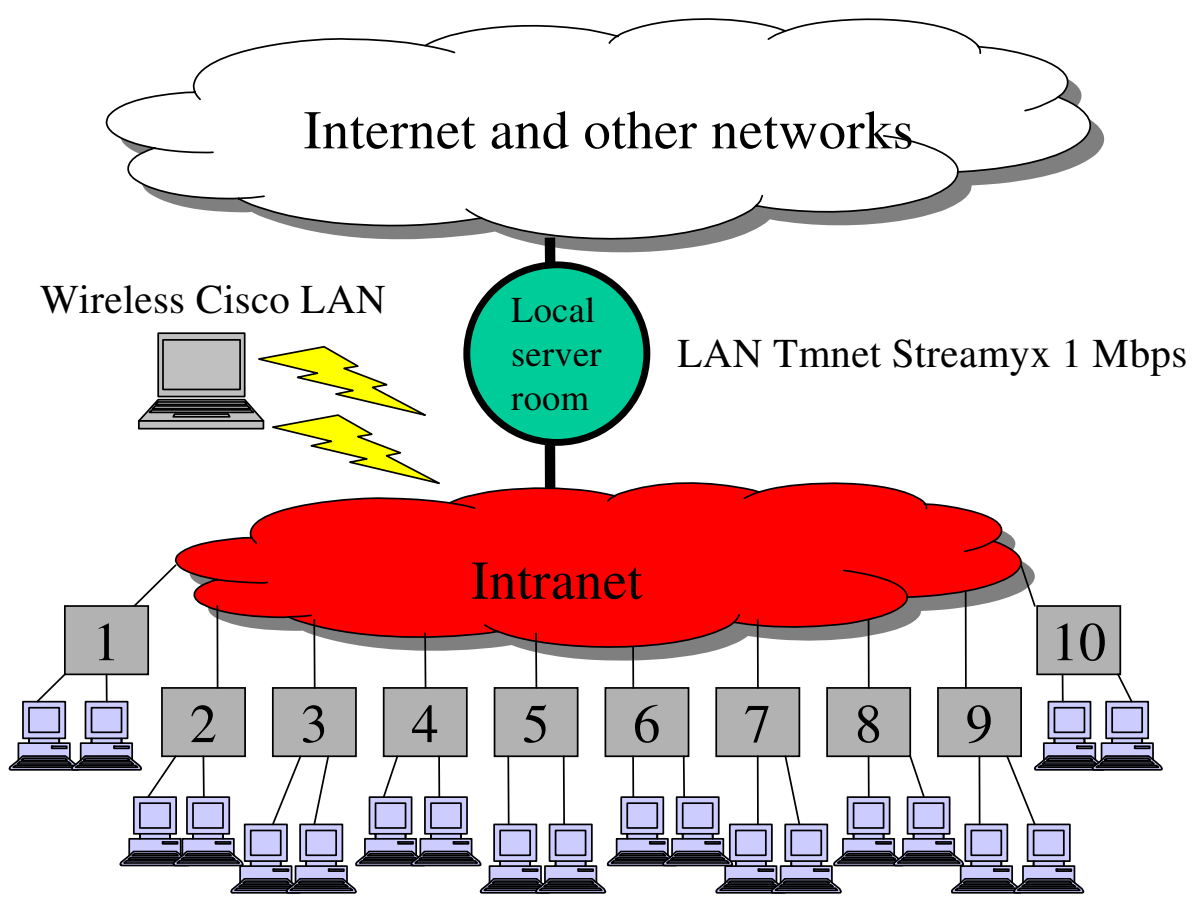

\begin{tabular}{|c|l|c|c|l|c|}
\hline $\mathbf{1}$ & Self-Access Learning Centre & 10 & $\mathbf{6}$ & Staff room 1 & 4 \\
\hline $\mathbf{2}$ & School Resource Centre & 5 & $\mathbf{7}$ & Staff room 2 & 4 \\
\hline $\mathbf{3}$ & Computer Laboratory & 40 & $\mathbf{8}$ & Department Heads' Office & 4 \\
\hline $\mathbf{4}$ & Information Technology Laboratory & 40 & $\mathbf{9}$ & Subject Panels' Room & 4 \\
\hline $\mathbf{5}$ & Language Laboratory & 20 & $\mathbf{1 0}$ & Main Office & 10 \\
\hline
\end{tabular}

Fig. 13. The School's Network Diagram Positioning the Location of Access for the Digital Library (Owner's View of Network) 


\subsection{Time: when can one use the digital library (when do things happen)}

The last column, "When" represents time, or the events to which the digital library responds in relation to time. This is useful for designing schedules, the processing architecture, the control architecture and timing systems. It is difficult to describe or address this column in isolation from the others, especially Column 2 (Process). At the strategic level, the planner describes Time as the business cycle and overall business events. As has been delineated in the digital library goals and objectives (Motivation Column), the digital library provides round-the-clock access. As the Internet is a $24 / 7$ medium, the digital library is available 24 hours a day, 7 days a week.

In the detailed model of owner's perspective, the Time Column defines when activities or processes are to happen. Based on the findings of the case study regarding the school's approach in using the digital library, the chronology of events (such as teacher's notification and requirement of the project, students choose topic, gather information, create report, obtain teacher's feedback, edit and submit report) indicating the processes that take place in the digital library environment populates owner's view of the Time Column. The designer defines the business events or the processes in the digital library, which cause specific data transformations and entity state changes to take place (Table 2). The business events populate the designer's view of the Time Column of the Zachman Framework used.

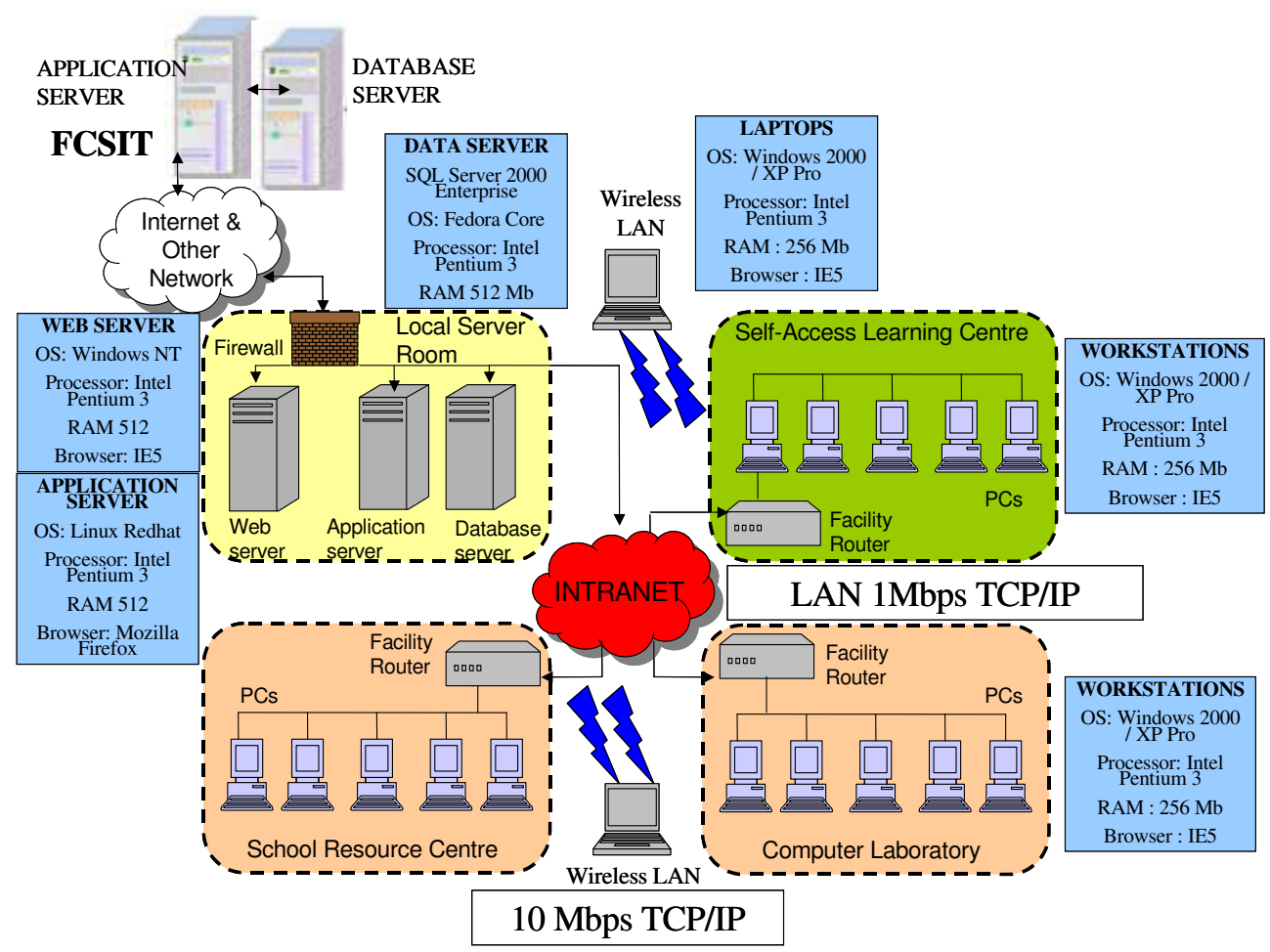

Fig. 14. The Digital Library Notional Distributed Systems Architecture (Designer's View of Nework) 


\begin{tabular}{l||l}
\hline \hline \multicolumn{1}{c||}{ The Process } & Data transformations and entity state changes to take place. \\
\hline \hline \multicolumn{1}{c}{ Students register } & $\begin{array}{l}\text { Students receive automatically generated e-mail notifying } \\
\text { membership of the digital library }\end{array}$ \\
\hline \hline $\begin{array}{l}\text { Students create and } \\
\text { submit report }\end{array}$ & $\begin{array}{l}\text { Teachers and Administrators receive automatically } \\
\text { generated e-mail notification indicating a new report has } \\
\text { been submitted and ready to be viewed, graded or indexed. }\end{array}$ \\
\hline \hline $\begin{array}{l}\text { Students create and } \\
\text { submit report }\end{array}$ & $\begin{array}{l}\text { Students receive automatically generated e-mail notification } \\
\text { indicating that they have successfully submitted their } \\
\text { project report. }\end{array}$ \\
\hline \hline $\begin{array}{l}\text { Administrator registers } \\
\text { teachers }\end{array}$ & $\begin{array}{l}\text { Teachers receive automatically generated e-mail notification } \\
\text { which indicates their User ID and Password. }\end{array}$ \\
\hline \hline $\begin{array}{l}\text { Teacher evaluate and } \\
\text { grade report }\end{array}$ & $\begin{array}{l}\text { Students receive automatically generated e-mail notification } \\
\text { indicating their projects have been evaluated. }\end{array}$ \\
\hline \hline
\end{tabular}

Table 2. Business Events in the Digital Library (Designer's View of Time)

\section{Conclusion}

This chapter has provided a detailed mapping between the first three layers of Zachman Framework for Enterprise Architecture and the concepts utilized in formulating the requirements and design of a digital library, based on a case study and analysis on building a collaborative digital library to meet the needs of the stakeholders. It has also illustrated the possibility of using the Zachman Framework as an instrument for requirements analysis and evaluation in digital development. The framework highlights the need to involve all possible stakeholders in the development of the architecture, not just the enterprise architects and developers, to ensure that it meets their needs and uses.

The perspectives and artifacts established from the framework have helped ensure that everything relevant to the digital library enterprise is covered. Table 3 shows the mapping of the Zachman Framework perspectives and dimensions with the collaborative digital library deliverables/aspects. The planner's perspective reflects the context that establishes the list of relevant constituents that must be accounted for in the descriptive representation for the other perspectives (owner and designer). The descriptive representation of owner's perspective reflects the usage characteristics of the digital library, what the owner is going to do with it and how they will use it once they get it in their possession. The descriptive representation of designer's perspective forms the basis for the design of the digital library system, as well as the features for manipulating the tangible aspects of the digital library.

Using Zachman Framework as the approach to design a digital library has contributed to the field of Enterprise Architecture by highlighting the fact that fusion of information technology with business is important and these two aspects should be addressed together in organizations. It has also contributed to another dimension of a framework for digital library research and development and "a structured vision for the development of new ideas" (Soergel, 2002). The collaborative digital library adheres to Soergel's guiding principles and ten themes for digital library research and development, as well as incorporates the dimensions of others' framework but instead of listing them as requirements or ticking against a checklist, the authors have embedded the requirements in a system's architectural framework and present them more systematically, taking into 


\begin{tabular}{|c|c|c|}
\hline DIMENSIONS & בZZACHMAN FRAMEWORK & "THE DIGITAL LIBRARY \\
\hline \multicolumn{3}{|c|}{ LEVEL 1: Objectives /Scope - Planner's View } \\
\hline $\begin{array}{l}\text { Motivation } \\
\text { (Why) }\end{array}$ & $\begin{array}{l}\text { Identify and list goals and objectives - } \\
\text { requirements analysis based on identified } \\
\text { objectives }\end{array}$ & $\begin{array}{l}\text { Motivating factors diagramme } \\
\text { Vision statement } \\
\text { List of DL goal } \\
\text { List of DL objectives }\end{array}$ \\
\hline Data (What) & $\begin{array}{l}\text { Identify \& list features / data important to the } \\
\text { repositories using needs survey from stack } \\
\text { holders }\end{array}$ & $\begin{array}{l}\text { DL resources in various media types } \\
\text { and format }\end{array}$ \\
\hline People (Who) & $\begin{array}{l}\text { Identify \& list all stack holders and their roles } \\
\text { in handing \& processing data - Roles analysis }\end{array}$ & DL organisational structure \\
\hline Function (How) & $\begin{array}{l}\text { Identify \& list processes the data performs - } \\
\text { stack holder's information use survey }\end{array}$ & $\begin{array}{l}\text { Activities students perform when } \\
\text { conducting history project in the DL }\end{array}$ \\
\hline $\begin{array}{l}\text { Location } \\
\text { (Where) }\end{array}$ & $\begin{array}{l}\text { Identify \& list locations where the enterprise } \\
\text { operates - information flow survey }\end{array}$ & The physical network of the DL \\
\hline Time (When) & $\begin{array}{l}\text { Identify \& list business events cycles - events } \\
\text { use analysis }\end{array}$ & Access to the DL (24/7) \\
\hline \multicolumn{3}{|c|}{ LEVEL 2: Business Conceptual Model - Owner's View } \\
\hline $\begin{array}{l}\text { Motivation } \\
\text { (Why) }\end{array}$ & $\begin{array}{l}\text { Business Plan Business plan - flow diagram / } \\
\text { rich picture }\end{array}$ & $\begin{array}{l}\text { Rich picture showing owners' } \\
\text { approach to use the DL } \\
\text { List of perceived benefits to use the } \\
\text { DL }\end{array}$ \\
\hline Data (What) & Entity relationships diagrams - rich picture & $\begin{array}{l}\text { DL Subject scope, collection and } \\
\text { resource criteria }\end{array}$ \\
\hline People (Who) & $\begin{array}{l}\text { Organisation charts, roles, set of skills \& } \\
\text { security issues - box charts / rich picture }\end{array}$ & DL actor-roles diagram \\
\hline Function (How) & $\begin{array}{l}\text { Business process model - flow diagram / rich } \\
\text { picture }\end{array}$ & $\begin{array}{l}\text { Conceptual model of services in the } \\
\text { DL }\end{array}$ \\
\hline $\begin{array}{l}\text { Location } \\
\text { (Where) }\end{array}$ & Logistics network - nodes and links & $\begin{array}{l}\text { Owner's network diagram } \\
\text { positioning the location of access for } \\
\text { the DL }\end{array}$ \\
\hline Time (When) & Business master schedules -rich picture & $\begin{array}{l}\text { Chronology of events in the DL } \\
\text { environment }\end{array}$ \\
\hline \multicolumn{3}{|c|}{ LEVEL 3: System Model - Designer's View } \\
\hline $\begin{array}{l}\text { Motivation } \\
\text { (Why) }\end{array}$ & Business rule model & $\begin{array}{l}\text { Behavioural objectives as DL } \\
\text { mandatory functional requirements }\end{array}$ \\
\hline Data (What) & Data model - entity diagrams & $\begin{array}{l}\text { Table definitions for the DL data; } \\
\text { metadata profile for the digital } \\
\text { objects resource description }\end{array}$ \\
\hline People (Who) & $\begin{array}{l}\text { System interfaces } \\
\text { roles, data, access }\end{array}$ & $\begin{array}{l}\text { Actors and their roles depicted in the } \\
\text { DL's three-tier client-server } \\
\text { architecture }\end{array}$ \\
\hline Function (How) & $\begin{array}{l}\text { Data flow diagram showing application of } \\
\text { data in the architecture }\end{array}$ & $\begin{array}{l}\text { Structured chart for programme } \\
\text { modules; users' menu }\end{array}$ \\
\hline $\begin{array}{l}\text { Location } \\
\text { (Where) }\end{array}$ & Diagram indicating how data is distributed & $\begin{array}{l}\text { The DL notional distributed systems } \\
\text { architecture }\end{array}$ \\
\hline Time (When) & $\begin{array}{l}\text { Process structure with dependency diagrams, } \\
\text { entity life history }\end{array}$ & Business events in the DL \\
\hline
\end{tabular}

Table 3. Mapping the Digital Library Deliverables to the Zachman Framework Perspectives and Dimensions 
account the following details, aligned with the emerging perspective of the Enterprise Architecture:

a. The vision, goals, objectives, business plans and the functional requirements of the digital library;

b. The types of resources, domain focus, collection and data definition of the digital library;

c. The stakeholders and users, their roles and functional roles in the digital library;

d. The activities users perform, service conceptual model and the digital library programme modules

e. The location of access, the network diagram and the notional distributed system architecture;

f. The availability, business cycle and overall business events

In alignment with the vision already expressed by the DLF (2005), the authors felt that digital library developers should "get out of the box" and give more attention to the development of conceptual frameworks giving preference to scopes, goals requirements and processes, in the sense as those concepts are already common in the classic Enterprise Architecture processes and Zachman Framework for Enterprise Architecture can be a very simple comprehensive reference for this. Perhaps is time for the digital library researchers and practitioners to recognize that the focus of the digital library should move from the perspective of the engineer, who are responsible for systems design, to the perspective of the architect who prepares, plans and develops specifications, that bridge the gap between the systems (that the engineers design) and what the community needs. Although this chapter defines the design process and constructs necessary for the development of a collaborative educational digital library for secondary schools with a particular focus in Malaysia, illustration of the detailed mapping between the first three layers of Zachman cells and the dimensions utilized in formulating the requirements and design of the digital library can facilitate design transferability so that it could also be applied in another country setting.

\section{References}

Abdullah, A \& Zainab A.N. (2006). Ascertaining factors motivating use of digital libraries and formulating user requirements using Zachman Framework. Malaysian Journal of Library Information Science Vol.11 No 2: 21-40, ISSN 1394-6234

Abdullah, A. \& Zainab, A.N. (2008). The digital library as an enterprise: The Zachman approach. The Electronic Library,Vol. 26, No. 4, 446-467, ISSN 0264-0473.

Blumenfeld, C., Soloway, E., Marx, R. W., Krajcik, J. S., Guzdial, M., and Palincsar, A. (1991). Motivating project-based learning: Sustaining the doing, supporting the learning. Educational Psychologist. Vol. 26, No. 3\&4, 369-398, ISSN 0046-1520

Bolton, G. (2004). What is Enterprise Architecture? Available at http://www.eacommunity.com/resources/whitepapers.asp

Borbinha, J. (2007). It is the time for the digital library to meet the enterprise architecture, Proceedings of the 10th International Conference on Asian Digital Libraries: looking back 10 years and forging new frontiers, ICADL2007. Lecture Notes in Computer Science, pp. 176-185, ISBN 978-3-540-77093-0, Hanoi, Vietnam December 10-13, 2007, Springer-Verlag, Berlin 
Castelli, D. \& Fox, E.A. (2007). Series of workshops on Digital Library Foundations. D-Lib Magazine, 13, 9/10 (Sept/Oct 2007), ISSN 1082-9873, Available at: http://www.dlib.org/dlib september07castelli/09castelli.html

Fuhr, N.; Hansen, P.; Mabe, M.; Micsik, A. \& Solvberg, T. (2001). Digital libraries: A generic classification and evaluation scheme. In Proceedings of the 5th European Conference on Research and Advanced Technology for Digital Libraries, ECDL2001. Lecture Notes in Computer Science, pp. 187-199, ISSN 0302-9743, Darmstadt, Germany, September 4-9 2001, Springer-Verlag, Berlin

Digital Library Federation. (2005). DLF service framework for digital libraries: A progress report for the DLF steering committee. Available at: http://www.diglib.org/architectures/serviceframe/dlfserviceframe1.htm

Gonçalves, M. A.; Fox, E. A.; Watson, L. T. \& Kipp, N. A. (2004). Streams, structures, spaces, scenarios, societies (5s): A formal model for digital libraries. ACM Trans. Inf. Syst. Vol. 22, No. 2 (Apr. 2004), 187-199, 270-3122163, Springer-Verlag, Berlin

Gladney, H.; Fox, E. A.; Ahmed, A.; Ashany, R.; Belkin, N. J. \& Zemankova, M. (1994). Digital library: Gross structure and requirements: Report from a March 1994 Workshop. In Proc. 1st Annual Conf. on the Theory and Practice of Digital Libraries, IBM Research Report RJ 9840

Kahn, R. \& Wilensky R. (1995). A framework for distributed digital object services. Available at: http://www.cnri.reston.va.us/cstr/arch/k-w.html

Lavoie, B, Henry G. and Dempsey. L. 2006. A service framework for libraries. D-Lib Magazine,. Vol. 12, no 7/8, (July/Aug, 2006) ISSN 1082-9873. Available at: http://www.dlib.org/dlib/july06/lavoie/07lavoie.html

Levy, D. \& Marshal, C. (1995). Going digital: A look at assumptions underlying digital libraries. Communications of the ACM. Vol. 38 , No. 4, 77-84, ISSN 0001-0782

Marchionini, G. \& Fox, E. A. (1999). Progress toward digital libraries: Augmentation through integration. Information Processing \& Management. Vol. 35, No. 3, 219-225, ISSN 0306-4573

McGovern, J.; Ambler, S.W.; Stevens, M.; Linn, J.; Sharan, V. \& Jo, E. (2003). The practical guide to Enterprise Architecture. ISBN-10: 0131412752, Englewood Cliffs, N.J. : Prentice-Hall

Moen, W.E. \& McClure, C.R. (1997). An evaluation of the U.S. Government's implementation of the Government Information Locator Service (GILS). Available at: http://www.unt.edu/slis/research/gilseval/gilsdocs.htm

Pereira, C.M. and Sousa, P. (2004). A method to define an Enterprise Architecture using the Zachman Framework. ACM Symposium on Applied Computing 2004, Nicosia, Cyprus, March 14-17.

Renda, E. M. and Straccia, U. (2004). A personalized collaborative digital library environment: a model and an application. Information Processing and Management. Vol. 14, No.1, 5-21, ISSN 0306-4573

Sandusky, R. J. (2002) Digital library attributes: Framing usability research. In Blandford, A. and Buchanan, G. (eds.) Proceeding Workshop on Usability of Digital Libraries at JCDL'02. (p. 35-38) 
Saracevic, T. \& Covi, L. (2000). Challenges for digital library evaluation. In Kraft, D. H. (ed.), ASIS 2000: Proceedings of the 63rd ASIS Annual Meeting, Vol. 37 (p. 341-350). Medford, NJ: Information Today

Schauble, P. \& Smeaton, A.F. (1998). Summary report of the series of joint NSF-EU working groups on future directions for digital library research: An international research agenda for digital libraries. Available at:

http://www.ercim.org/ publication/ws-proceedings

Soergel, D. (2002). A framework for digital library research: Broadening the vision. DLib

Magazine. Vol. 8, No. 12 (Dec 2002), ISSN 1082-9873. Available at: http:/ / www.dlib.org/dlib/december02/soergel/ 12soergel.html.

Zachman, J. A. (2002). Zachman International Enterprise Architecture. Available at: http://www.zachmaninternational.com/Default.htm 


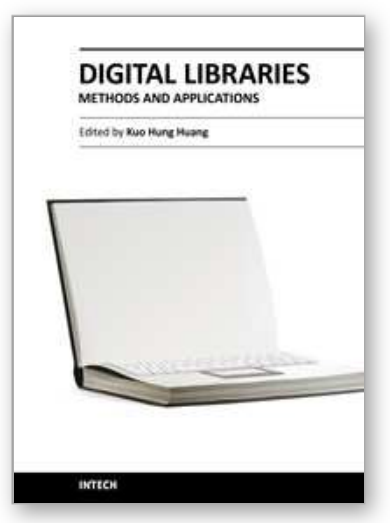

\author{
Digital Libraries - Methods and Applications \\ Edited by Dr. Kuo Hung Huang
}

ISBN 978-953-307-203-6

Hard cover, 220 pages

Publisher InTech

Published online 04, April, 2011

Published in print edition April, 2011

Digital library is commonly seen as a type of information retrieval system which stores and accesses digital content remotely via computer networks. However, the vision of digital libraries is not limited to technology or management, but user experience. This book is an attempt to share the practical experiences of solutions to the operation of digital libraries. To indicate interdisciplinary routes towards successful applications, the chapters in this book explore the implication of digital libraries from the perspectives of design, operation, and promotion. Without common agreement on a broadly accepted model of digital libraries, authors from diverse fields seek to develop theories and empirical investigations that to advance our understanding of digital libraries.

\title{
How to reference
}

In order to correctly reference this scholarly work, feel free to copy and paste the following:

A. Abrizah and A.N. Zainab (2011). Bringing the Digital Library Design into the Realm of Enterprise Architecture, Digital Libraries - Methods and Applications, Dr. Kuo Hung Huang (Ed.), ISBN: 978-953-307-2036, InTech, Available from: http://www.intechopen.com/books/digital-libraries-methods-andapplications/bringing-the-digital-library-design-into-the-realm-of-enterprise-architecture

\section{INTECH}

open science | open minds

\section{InTech Europe}

University Campus STeP Ri

Slavka Krautzeka 83/A

51000 Rijeka, Croatia

Phone: +385 (51) 770447

Fax: +385 (51) 686166

www.intechopen.com

\section{InTech China}

Unit 405, Office Block, Hotel Equatorial Shanghai

No.65, Yan An Road (West), Shanghai, 200040, China 中国上海市延安西路65号上海国际贵都大饭店办公楼 405 单元

Phone: +86-21-62489820

Fax: $+86-21-62489821$ 
(C) 2011 The Author(s). Licensee IntechOpen. This chapter is distributed under the terms of the Creative Commons Attribution-NonCommercialShareAlike-3.0 License, which permits use, distribution and reproduction for non-commercial purposes, provided the original is properly cited and derivative works building on this content are distributed under the same license. 